\title{
A TYPOLOGY OF HUNGARIAN TIME ADVERBS*
}

\author{
ANIKÓ CSIRMAZ \\ Linguistics Program \\ Carleton College \\ One North College St \\ Northfield, MN 55057 \\ USA \\ acsirmaz@carleton.edu
}

\begin{abstract}
Hungarian has a number of apparently synonymous time adverbs that can measure the duration of time intervals. The paper explores these adverbs in some detail, and argues that contrary to appearances, none of them are freely interchangeable. The starting point is a discussion of the property of homogeneity that time adverbs are sensitive to. The paper argues for a specific treatment of homogeneity and a preliminary adverb definition based on that treatment. It is proposed that some, but not all, Hungarian time adverbs share the default definition. The diverging adverbs may (a) contain a covert frequency predicate or (b) not measure the duration of the time interval directly, but by determining an endpoint of the interval. Hungarian time adverbs also differ in the range of time intervals they can measure; some, but not all adverbs can measure all available time intervals including the event, iterative, habitual and reference time. This variability in time adverb modification is arbitrary and needs to be explicitly determined for each adverb. Apart from discerning the interpretation of Hungarian time adverbs, the conclusions have a more general impact. On the one hand, apparently homogeneous adverbs can have disparate definitions. On the other, it is necessary to permit explicit, arbitrary constraints on adverbial modification. It is also argued that time adverbs can impose non-local restrictions on the eventuality modified, strengthening the need for a powerful theory of adverbial modification.
\end{abstract}

Keywords: aspect, duration, divisibility, adverbial modification, time interval

* For comments and discussions, I am grateful to Kai von Fintel, Danny Fox, Irene Heim, Sabine Iatridou, David Pesetsky, Katalin É. Kiss, Chris Piñón and the audience of the 30th Penn Linguistics Colloqium, the GLOW 29 Workshop on Adjuncts and Modifiers, the 16th Colloquium of Generative Grammar and of the workshop The Hungarian Language: Past and Present. The research reported here was partially funded by the OTKA grants TS 40705 and 49873. All errors are mine.

1216-8076/\$20.00 @ 2006 Akadémiai Kiadó, Budapest 
The present paper attempts to give a detailed characterization of Hungarian durative time adverbs. It is argued that the time adverbs which appear to be synonymous are not interchangeable; they encode a number of differences among one another. It is also pointed out that some Hungarian time adverbs impose unexpected and crosslinguistically marked restrictions on their arguments. More generally, the paper argues for varying treatments of homogeneity in eventuality descriptions and also argues for widening the range of time intervals that can be measured by time adverbs.

The paper is organized as follows. Section 1 introduces two classes of Hungarian and English time adverbs which are discussed in this paper. Section 2 elaborates on the properties of eventuality predicates and other predicates that the time adverb modification is sensitive to. Section 3 establishes a definition of English time adverbs, which also serves as the preliminary definition of Hungarian time adverbs. Sections 4 and 5 modify the preliminary definitions to describe the differences among Hungarian time adverbs and section 6 concludes the paper.

\section{Introduction}

The main focus of the paper is the group of adverbs that measure the duration of an eventuality, a category that includes both states and events, the latter a dynamic eventuality (Bach 1986). As often noted, these adverbs are sensitive to aspectual properties of the eventuality description. The type of eventuality description whose time the adverbs can measure is restricted; they either measure the time of an atelic eventuality description, or that of a telic one, as shown in (1). ${ }^{1}$

Before discussing the distribution of Hungarian time adverbs, let us briefly address the distinction between telic and atelic eventuality descriptions. One and the same event can be characterized in radically different ways: the eventuality of János running, for instance, can be described as in (1a) or as in (1b). A discussion of adverbial modification thus needs to appeal to properties of eventuality descriptions and not to those of events.

\footnotetext{
${ }^{1}$ The discussion is restricted to time adverbs that measure duration; punctual time adverbs are not addressed. Thus for the ease of discussion (and since the term durative adverb is sometimes restricted to adverbs measuring the time of atelic eventuality descriptions) I adopt the term time adverb to all adverbs measuring duration and apply it accordingly.
} 
(1) (a) János ran

ATELIC

(a') János ran for half an hour

(b) János ran to the store

TELIC

$\left(\mathrm{b}^{\prime}\right)$ János ran to the store in half an hour

The two descriptions have different properties, which are discussed in more detail in section $\mathbf{2}$. Intuitively, the atelic eventuality description in (1a) is homogeneous. As such, it can be applied, for instance, not only to a given eventuality, but also to a part or continuation of that eventuality. If János continues running after an hour and a half, then the longer running eventuality can still be described as János ran. Similarly, the eventuality description of János ran also holds during all parts of the 30minute interval described. Telic eventuality descriptions, such as (1b), behave differently. The eventuality description János ran to the store cannot be applied to all proper parts of the running event. Similarly, if János runs further, then the telic eventuality description cannot apply to this larger eventuality.

This homogeneity difference between telic and atelic eventuality descriptions is shown by a number of diagnostics (e.g., Smith 1991; Rothstein 2004). One of the most often cited diagnostics relies on temporal modification of eventualities. The duration of the event argument of an atelic eventuality description can be measured by a for-adverb (2a). That of an argument of a telic description, in contrast, is modified by an in-adverb (3a).

In Hungarian, four different durative adverbs can modify an atelic eventuality description $(2 \mathrm{~b}-\mathrm{d})$. I argue below that contrary to the initial impressions, these adverbs are not synonymous. In fact, the distribution or the interpretation of all of these adverbs is different, and they can impose different restrictions on the time intervals they measure.

(2) Adverbs measuring the time of an atelic eventuality description

(a) János ran / *ran to the store for an hour and a half

(b) János másfél órán át futott /*el futott a boltba J-nom one.and.half hour-on across ran away ran the store-to 'János ran / *ran to the store for an hour and a half'

(c) János másfél óráig futott /*el futotta boltba J-nom one.and.half hour-until ran away ran the store-to 'János ran / *ran to the store for an hour and a half' 
(d) János másfél órán keresztül futott / *el futott a boltba J-nom one.and.half hour-on across ran away ran the store-to 'János ran / *ran to the store for an hour and a half'

(e) János másfél órát futott $/ *^{*} \mathrm{el}$ futott a boltba J-nom one.and.half hour-acc ran / away ran the store-to 'János ran / *ran to the store for an hour and a half'

For telic eventuality descriptions, two types of adverbs modify duration in Hungarian. Similarly to the time adverbs in (2), I argue below that these adverbs are not synonymous but affect time intervals differently.

(3) Adverbs measuring the time of a telic eventuality description

(a) János ran to the store / *ran in an hour and a half

(b) János másfél óra alatt el futott a boltba / *futott

J-nom one.and.half hour under away ran the store-to ran

'János ran to the store / *ran in an hour and a half'

(c) János másfél órán belül el futott a boltba / *futott J-nom one.and.half hour-on inside away ran the store-to ran 'János ran to the store / *ran in an hour and a half'

Before turning to a detailed discussion of Hungarian time adverbs, let us discuss the characterization of (a)telicity and the semantics of time adverbs below. Section $\mathbf{2}$ explores diverse views of homogeneity and section 3 discusses the semantics of time adverbs in general.

\section{Properties of eventuality descriptions}

In order to characterize the difference between telic and atelic eventuality descriptions reliably, it is necessary to identify certain properties of eventuality descriptions. This section argues that the homogeneity of eventuality descriptions is best characterized in terms of divisibility rather than cumulativity. It is pointed out that the standard definition of divisibility or subinterval property runs into problems, and an alternative definition is adopted. It is also shown that the relevant notion of homogeneity cannot apply only to eventuality descriptions. It must be applicable to other predicates of times, such as those that take the reference time or the perfect time span as an argument. 


\subsection{Divisibility or cumulativity?}

As noted in the preceding section, atelic eventuality descriptions are homogeneous. Homogeneity is usually described in terms of divisibility and/or cumulativity, both of which are properties of predicates (Smith 1991; Rothstein 2004; Krifka 1998, among others). Divisible predicates hold for a given argument and all of its parts. Cumulative predicates, in turn, apply not only to atomic arguments, but also to their union.

(4) (a) A predicate $P$ is divisible iff whenever $P(x)$, then $\forall y \subseteq x \rightarrow P(y)$

(b) A predicate $P$ is cumulative iff whenever $P(x)$ and $P(y)$, then $P(x \oplus y)^{2}$

In order to apply the definitions of divisibility or cumulativity to eventuality descriptions, it is necessary to introduce specific assumptions. I assume that eventuality descriptions take, among others, a time interval argument $t$, the event time. ${ }^{3}$ The predicate of times applying to the event time is the event time predicate. Divisibility and cumulativity, as defined in (4), apply to the predicate of times $(P)$ and the time interval argument of that predicate $(t)$, as illustrated below.

(5) (a) János run is divisible

$($ János run $)(t) \rightarrow \forall t^{\prime} \subset t \rightarrow($ János run $)\left(t^{\prime}\right)$

(b) János run is cumulative

$($ János run $)(t) \&($ János run $)\left(t^{\prime}\right) \rightarrow($ János run $)\left(t \oplus t^{\prime}\right)^{4}$

Since both divisibility and cumulativity hold only of atelic eventuality descriptions but not of telic ones, either property appears to be sufficient to distinguish the two types of predicates. With atelic eventuality descriptions, divisibility and/or cumulativity holds for the event time predicate $(P)$ and the event time $(t)$. If the eventuality description is telic, then the event time predicate is neither divisible nor cumulative. ${ }^{5}$

${ }^{2}$ I assume that eventualities, similarly to locations and individuals, can be temporally and spatially discontinuous.

${ }^{3}$ In this paper, I am agnostic about whether the predicates have an event argument, or even whether events exist. Appealing to time intervals rather than events in determining telicity allows for a more general treatment. Homogeneity can be straightforwardly extended to predicates that apply to times other than the event time (e.g., the reference time), as discussed below.

${ }^{4}$ Time intervals - like eventualities - can be discontinuous.

${ }^{5}$ The view of telicity as the property of the event time predicate (in contrast with (im)perfectivity, as discussed below) assumes a two-component theory of 
As they stand, however, neither property identifies the range of atelic and telic eventuality descriptions properly. First, let us consider granularity, a shortcoming of the property of divisibility.

Given the predicate of times of an atelic eventuality description, that predicate does not necessarily apply to all the subintervals of that argument (discussed in Hinrichs 1985; Rothstein 2004; Bertinetto 2001; among others). Consider the atelic examples in (6).

(6) (a) János ran (for ten minutes)

(b) János futott

J-nom ran

'János ran'

(c) János was sick (for two days)

(d) János beteg volt

J-nom sick was

'János was sick'

A state, as in $(6 \mathrm{c}, \mathrm{d})$, holds for all the subintervals of the time argument, here a two-day-long time interval. For an activity such as running $(6 a, b)$, in contrast, this is not the case. Activities show the granularity effect: the time interval argument contains atomic time intervals for which the predicate of times - in this case János run - is not true. The predicate fails to hold, among others, for the time interval during which he only lifts his right heel off the ground. ${ }^{6}$ Since divisibility, as defined above, requires the predicate in question to hold of all parts of the argument, a number of atelic eventuality descriptions - specifically, all activitiesfail to qualify as divisible.

aspect, as in Smith (1991), Olsen (1997), Bertinetto (2001), and others. In this theory, the property of telicity ('situation aspect') is crucially distinct from that of (im)perfectivity (the 'viewpoint aspect'). The difference is encoded here as homogeneity applying to distinct time intervals: the event time for telicity, and the reference time for (im)perfectivity (cf. section 2.2).

${ }^{6}$ The lack of the granularity effect has been suggested as the property (or one of the properties) distinguishing states and dynamic, non-stative divisible eventuality descriptions (for instance, Vendler 1967; Dowty 1979; Comrie 1976; Smith 1991; and Bertinetto 2001). As argued by Csirmaz (to appear), non-granularity does not hold of states only, but can also be true of other predicates of times, including reference time intervals discussed in section 2.2. Homogeneity without granularity thus cannot identify stative descriptions. Rather, states can be identified by either (a) restricting strict, non-atomic homogeneity to event predicates, or (b) by appealing to a different property such as inertia (lack of dynamicity), a property that holds only of states.

Acta Linguistica Hungarica 53, 2006 
As noted above, telic eventuality descriptions are not cumulative. It may suffice then to adopt cumulativity, repeated below, as the relevant property distinguishing telic and atelic eventuality descriptions.

(7) A predicate $P$ is cumulative iff whenever $P(x)$ and $P(y)$, then $P(x \oplus y)$

Cumulativity does not encounter the problem of granularity. It identifies János run as cumulative and therefore atelic, in spite of the existence of atomic time intervals where the predicate János run does not hold. While it handles the distinction between atelic and telic eventuality descriptions successfully, cumulativity fails in predicting the range of adverbs modifying other time intervals. A time interval other than the event time and its interaction with time adverbs, cumulativity and divisibility is addressed in the following section.

\subsection{Reference time and predicates}

The preceding discussion was concerned with properties of the event time predicate and adverbial modification. It is not only the event time that can be measured by time adverbs, though. In (8), for instance, it is not the event time but the perfect time span that is modified; there is a twoyear-long interval, during which János lived in Spain, which extends in the past from the speech time backwards.

(8) János has lived in Spain for two years

Apart from the event and perfect times, other time intervals can also be measured by time adverbs.

\subsubsection{Reference time}

Csirmaz (2005; 2006; to appear) notes that the reference time can also be modified by a time adverb. The reference time - or topic time - is the time interval under discussion, which can be ordered in a number of different ways with respect to the event time and the time of utterance. As argued by Klein (1994), Iatridou et al. (2001), von Stechow (2002) and others, the relative ordering of the reference time and the event time yields the perfective or imperfective viewpoint of an eventuality description. ${ }^{7}$

${ }^{7}$ Demirdache and Uribe-Etxebarria $(2000 ; 2004)$ argue for a related but essentially different view of time intervals. They assume that the possible orderings for time

Acta Linguistica Hungarica 53, 2006 
(9) (a) János ran

(b) János was running

In the perfective (9a), the event time is properly contained within the reference time, hence the intuition that the sentence focuses on or asserts the complete event of running. In the imperfective (9b), in contrast, the reference time is a proper subinterval of the event time. An imperfective eventuality description thus focuses on a part of the eventuality rather than on the eventuality as a whole. The definitions, based on Iatridou et al. (2001) and von Fintel-Iatridou (1997), are given below.

(10) (a) $\llbracket$ perfective $\rrbracket=\lambda P \cdot \lambda t \cdot \exists t^{\prime} \cdot\left[t^{\prime} \subset t \& P\left(t^{\prime}\right)\right]$

(b) $\llbracket$ imperfective $\rrbracket=\lambda P \cdot \lambda t \cdot \exists t^{\prime} \cdot\left[t \subset t^{\prime} \& P\left(t^{\prime}\right)\right]$

( $t$ : reference time; $t^{\prime}$ : event time)

Similarly to the event time, the reference time can also be measured by a time adverb. In English, it is possible for both the event time and the reference time to be modified at the same time (as noted in de Swart 1998 , for instance): ${ }^{8}$

(11) For half an hour, János was running the distance in ninety minutes (but then he realized that he wouldn't be able to complete it in time)

The adverb for half an hour measures the reference time of the imperfective eventuality description, and in ninety minutes specifies the duration of the event time. Thus, as shown by the possibility of perfect and reference time modification, the treatment of time adverbs should not appeal to properties of the event time only (contrary to Moltmann 1991, among others).

intervals are consecutive ordering and inclusion. For the event time and their assertion time, this ordering yields either a perfect or an imperfective eventuality description. The system makes it impossible to represent and account for (nonperfect) perfective eventuality descriptions. Csirmaz (2006) argues that given the existence of non-perfect perfective eventuality descriptions, and that of languages that overtly mark such descriptions, it is more attractive to adopt the system outlined above. The topic and event times can be ordered by inclusion, and the perfect time is optionally present in the time structure of the description. The reference time and the time of utterance can be ordered by precedence or containment, as in past and present tense eventuality descriptions, respectively.

${ }^{8}$ Similar examples are ungrammatical in Hungarian, as discussed in section $\mathbf{5}$. 


\subsubsection{Homogeneity as divisibility}

The modification of reference time helps to refine the criteria for determining predicate homogeneity. As pointed out earlier, the granularity of atelic event descriptions argues against determining homogeneity in terms of divisibility. If homogeneity is seen as cumulativity, then the problem of granularity and atomic time intervals does not arise. The possibility of reference time modification, however, suggests that it is divisibility that should be viewed as the relevant criterion of homogeneity.

It was noted by Bennett-Partee (1972) and Dowty (1979) among others that all negated eventuality descriptions can be modified by a foradverb, including telic and perfective descriptions. For-adverb modification shows that negation yields a homogeneous eventuality description:

(12) (a) For half an hour, János didn't arrive

$\left(\mathrm{a}^{\prime}\right)^{\#}$ For half an hour, János arrived

(b) János fél óráig nem érkezett meg J-nom half hour-until not arrived perf 'For half an hour, János didn't arrive'

$\left(\mathrm{b}^{\prime}\right)$ \#János fél óráig meg érkezett J-nom half hour-until perf arrived 'For half an hour, János arrived'

In addition, for-adverbs can also modify all eventuality descriptions with a decreasing argument or those with a constituent modified by only. Again, the telicity and perfectivity of the eventuality description is irrelevant. The eventuality descriptions below are telic and perfective, yet modification by a for-adverb or a Hungarian counterpart is grammatical.

(13) (a) For half an hour, fewer than three guests arrived

(b) Fél óráig kevesebb, mint három vendég érkezett meg half hour-until fewer than three guest-nom arrived perf 'For half an hour, fewer than three guests arrived'

(14) (a) For four months, only János completed the course (the others didn’t manage to do so)

(b) Négy hónapig csak János végezte el a tanfolyamot four month-until only J-nom completed away the course-acc 'For four months, only János completed the course' 
Csirmaz (2005; 2006; to appear) argues that in these cases the time adverbs modify the reference time, whereas the properties of the event time - including telicity and duration - remain unaffected. Modification by for-adverbs and their Hungarian equivalents is thus not a diagnostic of the homogeneity of eventuality descriptions. Rather, the time adverbs can ascertain the homogeneity of diverse predicates of time - that of the predicate applying to the event time, the reference time, or the perfect time span.

Let us assume that the semantics of for-adverbs is uniform, and that for-adverbs only modify predicates of times that are homogeneous in a certain uniform sense. Given this assumption, the preceding data enforce the view of homogeneity that appeals to divisibility rather than to cumulativity. Consider the eventuality description with a monotone decreasing argument, as in (13). The for-adverb measures the duration of the reference time rather than that of the event time, since the event time predicate is not homogeneous.

The predicate of times which applies to the reference time in (13) is clearly not cumulative. If two guests arrived during a time interval $t$ and one guest arrived during time $t^{\prime}$, then for both $t$ and $t^{\prime}$ it holds that fewer than three guests arrived during those intervals. During the union of $t$ and $t^{\prime}$, however, it is exactly three guests that arrived - the predicate fewer than three guests arrived thus does not hold for $t \oplus t^{\prime}$. Thus even though cumulativity fails to encounter the problem of granularity, it cannot identify the set of homogeneous predicates of times, which can be modified by a for-adverb. ${ }^{9}$

\subsection{Two approaches to divisibility}

\subsubsection{Granularity and contextual restriction}

Since cumulativity cannot determine homogeneity for time adverb modification, divisibility must be adopted instead. It is necessary then to avoid the granularity problem by altering the original definition of divisibility, repeated below.

${ }^{9}$ Divisibility as the property determining homogeneity does not account for the for-adverb modification licensed by only, illustrated in (14). To account for this, I introduce the notion of Strawson divisibility (building on Strawson entailment (von Fintel 1999)), which requires divisibility to hold only for those time intervals where the predicate of times is defined. Strawson divisibility is discussed in more detail in section $\mathbf{3 . 3}$.

Acta Linguistica Hungarica 53, 2006 
(15) A predicate $P$ is divisible iff whenever $P(x)$, then $\forall y \subseteq x \rightarrow P(y)$

A number of authors (more recently Moltmann 1991; Bertinetto 2001; Rothstein 2004) suggested that the universal quantification over parts of arguments still holds, but is constrained by some contextual restriction. This restriction ensures that the predicate of times does not need to hold for all subintervals, but only for those which are not excluded by that restriction. Even though this appears to be a viable way to salvage divisibility as the relevant condition of homogeneity, a number of problems arise.

First, as noted by Hinrichs (1985), the nature of the contextual restriction is a highly pragmatic matter. The length of atomic time intervals for the predicate János run can be affected, among others, by the age or physical properties of János, the agent. If divisibility is treated as a semantic property, however, then these pragmatically affected restrictions cannot be incorporated.

In addition, even within the domain of semantics proper, granularity (the existence of atomic time intervals) leads to circularity: the contextual restriction approach must assume that whenever a divisible predicate applies to an argument, it must also apply to all parts of that argument to which the predicate could apply. As an illustration, consider the following example:

(16) (a) the statue stood on the square

(b) a szobor a téren állt the statue-nom the square-on stood 'the statue stood on the square'

The stative description the statue stand on the square is divisible - an uncontroversial matter, since the event predicate is not granular. The eventuality description may contain a non-divisible time adverb, as in (17). ${ }^{10}$ The resulting eventuality description becomes non-divisible, since the duration of the eventuality description is delimited.

(17) (a) the statue stood on the square for a hundred years

(b) a szobor száz évig állt a téren

the statue-nom hundred year-until stood the square-on

'the statue stood on the square for a hundred years'

${ }^{10}$ Specifically, the time adverb takes a time interval argument and the adverb is non-divisible with respect to that time interval.

Acta Linguistica Hungarica 53, 2006 
Whenever the time adverb is divisible, as with the bare plural centuries or its Hungarian equivalent, the predicate is still homogeneous - that is, divisible - after temporal modification:

(18) (a) the statue stood on the square for centuries

(b) a szobor évszázadokig állt a téren

the statue-nom centuries-until stood the square-on

'the statue stood on the square for centuries'

The homogeneity of the resulting eventuality description cannot be shown by adverbial modification. Nevertheless, intuitively the homogeneity holds for the description, since the endpoint of the time during which the description holds is not specified. Assuming that homogeneity can always be equated with divisibility, the eventuality description in (18) must be divisible.

The time interval during which the divisible eventuality description holds is highly granular; while the description is homogeneous, homogeneity does not apply for all subintervals. The atomic subintervals are one hundred year long, since the atoms are those intervals to which the predicate egy évszázadig ('for a century') or century can apply. ${ }^{11}$ Given this condition on atomic times, (18) is homogeneous, similarly to other iterative or habitual eventuality descriptions.

To account for examples such as (18), an approach that appeals to contextual restriction on universal quantification needs to assume that the atomic time intervals are those intervals for which the predicate can hold. In the present case, the atomic time intervals measure one hundred years, as noted above. This restriction of atomic time intervals is rather circular, since it determines those predicates as divisible which satisfy the following condition: the predicate applies to an argument and all parts of that argument to which in can apply.

The circularity of atomic time intervals and arguments is also found elsewhere; it is revealed by all predicates of time that have sufficiently long atomic intervals. The following examples are all homogeneous and can be modified by for-adverbs and certain Hungarian equivalents of these adverbs. ${ }^{12}$ As before, the homogeneity of the predicate is ensured

${ }^{11}$ Bare count nouns are cumulative in Hungarian, thus a numeral or determiner is required to denote a time interval that is 100 years long.

12 The restriction on Hungarian equivalents of for-adverbs in modifying habitual and iterative eventuality descriptions is discussed in section 4 in more detail.

Acta Linguistica Hungarica 53, 2006 
only if the atomic intervals are defined as intervals which are possible arguments of the predicate.

(19) (a) János built churches

(b) János templomokat épített

J-nom churches built

'János built churches' (possible interpretation: 'built complete churches')

(20) (a) János wrote novels

(b) János regényeket írt

J-nom novels-acc wrote

'János wrote novels' (possible interpretation: 'wrote complete novels')

Thus both the pragmatic restriction and circularity present a problem for the approach that assumes a contextual restriction on universal quantification.

\subsubsection{A modified view of divisibility}

In order to avoid the problem created by granularity and the non-feasibility of contextual restriction on atomic arguments, Hinrichs (1985) and von Fintel (1997) propose a more complex definition of divisibility.

(21) A predicate $P$ is divisible iff whenever $P(x)$ for an argument $x$, then for all $y \subset x, \exists z[y \subseteq z \subset x \& P(z)]$

(all proper parts of $x$ must be parts of $P$-arguments) (based on Hinrichs 1985)

(22) A predicate $P$ is divisible iff whenever $P(x)$ for an argument $x$, then $x=\oplus_{\mathrm{NT}}\{y: P(y)\}$

( $x$ is the (non-trivial) sum of a set of $P$-arguments)

(von Fintel 1997)

Both definitions ensure that a time interval which serves as the argument of a divisible predicate of times has at least two disjoint subintervals that are also arguments of the predicate. This definition of divisibility avoids the problem of atomic predicates noted above, since the predicate does not need to apply to all subintervals. In addition, unlike cumulativity, it permits identifying the reference time of predicates with a decreasing argument as homogeneous.

Adopting this view of divisibility, the correlations between predicates of times and adverbial modification can thus be noted as in (23). 
(23) (a) A divisible predicate of times can be modified by a for-adverb

(b) A non-divisible predicate of times can be modified by an in-adverb

Note that no claims have been made about the distribution of the Hungarian equivalents of these adverbs. As emphasized earlier, I will argue that the distribution of Hungarian time adverbs differs among the various time adverbs. The generalizations concerning the distribution of English time adverbs and the definitions of these adverbs, discussed below, serve as a starting point for the differences among Hungarian time adverbs.

\section{Time adverbs and time intervals}

In the preceding section I argued that the homogeneity of atelic eventuality descriptions is best described as divisibility in the sense of Hinrichs (1985) and von Fintel (1997). Divisibility extends not only to event time predicates (distinguishing telic and atelic eventuality descriptions), but also to perfect and reference time predicates. For-adverbs can thus measure event times, reference times and perfect times, assuming that the predicate applying to the time interval is divisible. In-adverbs, in contrast, measure a time interval if the predicate of times is non-divisible.

Before turning to Hungarian time adverbs, let us determine a definition for the English for and in-adverbs. These will be adopted as the preliminary definitions for Hungarian time adverbs.

\subsection{A first approach}

Of the two time adverb classes, let us discuss for-adverbs and their equivalents - henceforth A-adverbs - first. As before, I assume the existence of time intervals $(t)$ and predicates of time $(P)$. Based on the preceding discussion, the approaches that assume the standard definition of divisibility (4a) or divisibility constrained by contextual restriction all encounter problems with granularity. Thus the accounts of Zucchi (1991), Moltmann (1991) and others, which incorporate this notion of divisibility in the denotation of a for-adverb, need to be modified.

An alternative definition of A-adverbs, based on (the divisibility definition of) Hinrichs (1985) and von Fintel (1997), is given below. The adverb takes a predicate of times and a time interval argument. The 
predicate of times argument must be divisible, ensuring that only divisible predicates of time can be modified by A-adverbs. ${ }^{13}$

(24) for twenty minutes $=\lambda P \cdot \lambda t \cdot\left[\forall t^{\prime} \subset t\left[\exists t^{\prime \prime}\left[t^{\prime} \subseteq t^{\prime \prime} \subset t \& P\left(t^{\prime \prime}\right)\right]\right] \&|t|=20\right.$ minutes $]$

Even though this definition ensures that the adverb cannot modify nondivisible predicates of times, at first blush it seems to run afoul on iterative and habitual eventuality descriptions. Both of the latter can be modified by an A-adverb: ${ }^{14}$

(25) (a) János ran for three years

(HABITUAL)

(b) János három évig futott

J-nom three year-until ran

'János ran for three years'

13 The adverb also has a measure argument which specifies the length of the time interval. For simplicity, I treat this measure argument as part of the adverb in this paper. It is worth noting, however, that the measure arguments have a maximality implicature which can be cancelled:

(i) János fél óráig fel mosott

J-nom half hour-until up washed

'János washed the floor for half an hour'

(ii) Sőt, volt az egy óra is

even was that one hour too

'It lasted an hour, even'

The implicature cannot be cancelled if the adverb is in immediately preverbal position.

(iii) János fél óráig mosott fel

J-nom half hour-until washed up

'János washed the floor for half an hour'

(iv) ${ }^{\#}$ Sőt, volt az egy óra is

even was that one hour too

'It lasted an hour, even'

The effect of preverbal position on the cancellability of maximality implicatures is not unique to these adverbs, but holds for other constituents that introduce an implicature as well. See É. Kiss (in press) for a recent discussion.

${ }^{14}$ As discussed in section 4, distinct types of Hungarian A-adverbs differ in whether they can modify an iterative or habitual eventuality description.

Acta Linguistica Hungarica 53, 2006 
(26) (a) János knocked for ten minutes (ITERATIVE)

(b) János tíz percig kopogott J-nom ten minute-for knocked

'Janos knocked for ten minutes'

Iterative and habitual eventuality descriptions can contain gaps where the event predicate does not hold. János does not need to run continuously during the three years in (25). Similarly, there can be times during the ten-minute interval in (26) when he is not knocking. The predicates of times applying to the three-year and ten-minute interval must then be divisible and still allow gaps. ${ }^{15}$

The notion of divisibility proposed earlier and the definition of A-adverbs above require that all subintervals of the time argument $t$-including gaps - be contained in some interval $t^{\prime}$ for which the predicate of times holds. This requirement fails for instantaneous eventualities such as the event János knock, which only holds for atomic, momentary time intervals. Gaps between running eventualities, as in (25), are also different from the atoms that the definition of divisibility handles successfully; it is not necessarily the case that the predicate of times János run extends over the three-year-long interval.

An alternative definition of A-adverbs explored in the following section readily accounts for the existence of gaps. It is argued that the original definition is more attractive, and that the problem of gaps can be resolved with this definition as well.

\subsection{Gaps and divisibility}

The definition of A-adverbs, as assumed above, does not seem to permit modification of a time interval containing gaps. The incompatibility of these adverbs and gaps is predicted because, given the definition of divisibility in (27), the maximal time intervals of habitual and iterative eventuality descriptions are non-divisible with respect to the event time predicate.

${ }^{15}$ Gaps differ from atomic time intervals, which give rise to the granularity effect. For gaps time intervals, there is a time argument of the predicate of times that contains the gap. For gaps, no such interval needs to exist; the gap is a time interval which is both preceded and followed by other time intervals that serve as arguments of the predicate.

Acta Linguistica Hungarica 53, 2006 
(27) A predicate $P$ is divisible iff whenever $P(x)$ for an argument $x$, then for all $y \subset x, \exists z[y \subseteq z \subset x \& P(z)]$

(all proper parts of $x$ must be parts of $P$-arguments) (based on Hinrichs 1985)

Contrary to what is predicted, both habitual and iterative eventuality descriptions permit modification by A-adverbs, as noted above and repeated below for the habitual (28) and the iterative (29).

(28) (a) János ran for three years

(b) ános három évig futott

J-nom three year-until ran

'János ran for three years'

(29) (a) The lamp blinked for ten minutes

(b) A lámpa tíz percig pislogott the lamp-nom ten minute-until blinked

'The lamp blinked for ten minutes'

If the predicate of times argument of A-adverbs must be divisible, then the definition of divisibility needs to be revised. Divisibility must allow the time intervals modified to contain not only atomic time intervals but also gaps.

Piñón (1999), after pointing out these problems, suggests that foradverbs neither measure the duration of some time interval nor involve quantification over subintervals. In order to account for the possible presence of gaps, he suggests that A-adverbs take a (possibly implicit) frequency predicate argument, which specifies the frequency of appropriate eventualities within the time interval in question. The frequency predicate $R$ takes an eventuality, a time interval and an eventuality type as arguments. Eventualities of type $P$ are repeated throughout the time interval $t$ with the frequency specified (the relation of repetition explicitly specified by Piñón 1999).

(30) for twenty minutes $=\lambda R \lambda P \lambda e[\exists t[[20 \text { minute }](t) \& R(e, t, P)]]^{16}$

If there is no overt frequency predicate, the A-adverb can be interpreted differently. In that case it is possible that there is an event with a runtime that is coextensive with the time interval $t$, and for which the eventuality

${ }^{16}$ Piñón (1999) also lists the measure phrase as an argument of the for-adverb. 
predicate is true. The event is not necessarily iterated or repeated, and thus the adverb can measure the duration of a single event. ${ }^{17}$

The adoption of a frequency predicate solves the problem of gaps. The problem of granularity is resolved by the assumptions concerning the alternative form of the adverb, which can appear in absence of an overt frequency adverb. In the latter case the eventuality predicate is not required to be true at all subintervals of the time interval modified, so the issue of atomic time intervals does not arise.

It was noted in section $\mathbf{2}$ that for-adverbs can modify not only event times, but also other time intervals. If Piñón's proposal is adopted without modifications, then for-adverbs are restricted to event time modification only. The definition can be modified such that the adverbs take not an eventuality, but a time interval argument. With the A-adverb denotation with overt frequency predicates, the frequency predicate applies to the time interval $t$, and $\mathrm{P}-$ a predicate of times - holds throughout $t$.

(31) for twenty minutes $=\lambda R \lambda P \lambda t\left[\exists t^{\prime}\left[[20\right.\right.$ minute $\left.\left.]\left(t^{\prime}\right) \& R\left(t, t^{\prime}, P\right) \& P(t)\right]\right]$

Similarly, the alternative entry of the adverb can also be rephrased and refer to time intervals rather than events or event times.

While the suggested modification resolves the issue of restricted time modification, there are still two entries of A-adverbs that are necessary to account for the readings of the adverb. With a different view of the status of gaps, it may be possible to maintain a unique definition of A-adverbs. ${ }^{18}$

I suggest that the definition of A-adverbs based on Hinrichs (1985) and von Fintel (1997) is, in fact, an adequate definition that handles both gaps and atomic intervals. The definition of A-adverbs in question is repeated below from (24).

(32) for twenty minutes $=\lambda P \cdot \lambda t \cdot\left[\forall t^{\prime} \subset t\left[\exists t^{\prime \prime}\left[t^{\prime} \subseteq t^{\prime \prime} \subset t \& P\left(t^{\prime \prime}\right)\right]\right] \&|t|=20\right.$ minutes $]$

17 The alternative denotation (with $Q$ a measure predicate) from Piñón (1999) is given as follows:

$$
\begin{aligned}
& \text { for }=\lambda Q \lambda P \lambda e\left[\exists t \left[Q ( t ) \& \operatorname { R e p } ( e , t , P ) \& \diamond \exists e ^ { \prime } \left[\tau\left(e^{\prime}\right)=\right.\right.\right. \\
& =t \& P\left(e^{\prime}\right) \rightarrow \forall t^{\prime}\left[\operatorname{Pause}\left(t^{\prime}, t, e, P\right) \rightarrow\right. \\
& \text { Interrupt } \left.\left(t^{\prime}, t, e, P\right)\right] \& \neg \diamond \exists e^{\prime}\left[\tau\left(e^{\prime}\right)=t \& P\left(e^{\prime}\right)\right] \rightarrow \\
& \neg \operatorname{Con}(e) \& \forall t^{\prime}\left[t^{\prime} \subseteq t \& S\left(t^{\prime}\right) \& \exists e^{\prime}\left[e^{\prime} \subseteq e \&\left(e^{\prime}\right) \subseteq t^{\prime} \& P\left(e^{\prime}\right)\right]\right]
\end{aligned}
$$

${ }^{18}$ In section 4 , it is argued that the first entry of the for-adverb must be adopted (in a modified form) for some Hungarian A-adverbs. Thus while the "default" A-adverb definition is different, Pinón's definition must still be adopted in some cases. 
Contrary to initial appearances, gaps do not present a problem for this definition; iterative as well as habitual eventuality descriptions qualify as divisible. They are divisible since the definition applies to the habitual and iterative predicates of times rather than to the event time predicates themselves. That is, the habitually or iteratively recurring event does not need to be expressed as a divisible event predicate. Rather, iterative and habitual eventuality predicates can hold of time intervals even when the event that recurs habitually or iteratively is not true.

(33) (a) [HAB (János run)](t)

(b) [ITER (lamp blink)](t)

Divorcing the iterative/habitual predicate from the event time predicate (which describes the iteratively/habitually recurring event) successfully accounts for the apparent problem of gaps. This view makes it necessary to establish not only event time and reference time, but also a habitual time and iterative time. In addition to these times, there are also predicates of times applying to these time intervals.

\subsection{Downward entailing quantifiers, only and adverbs}

Downward entailing quantifiers, mentioned in section 2.2, also support adopting the definition based on Hinrichs (1985) and von Fintel (1997) and disfavors a modification of the treatment of Piñón (1999). Recall that downward entailing quantifiers permit A-adverb modification even if in absence of these quantifiers, A-adverbs are marked. Licensing is illustrated below, repeated from (13).

(34) (a) For half an hour, \# (fewer than) three guests arrived

(b) Fél óráig \#(kevesebb, mint) három vendég érkezett meg half hour-until fewer than three guest-nom arrived perf 'For half an hour, fewer than three guests arrived'

It was observed above that divisibility, as defined based on Hinrichs (1985) and von Fintel (1997), handles these facts straightforwardly. In addition, a modification of divisibility also extends to A-adverb licensing by only, as in the example repeated from (14). 
(35) (a) For four months, only János completed the course (the others didn't manage to do so)

(b) Négy hónapig csak János végezte el a tanfolyamot four month-until only J-nom completed away the course-acc 'For four months, only János completed the course'

The reference time predicate, when modified by only, holds for only those subintervals that contain the event time. The predicate is not divisible according to the definition adopted; it is not true that all subintervals are contained in a proper subinterval for which the predicate holds. The definition of divisibility must thus be modified to ensure divisibility of this predicate.

A successful treatment of the A-adverb modification of reference time predicates with only requires several ingredients. Among others, (a) the introduction of the notion of Strawson divisibility, where the divisibility only needs to hold for a subset of the subintervals (for the subintervals where the predicate is interpreted $)^{19}$ and (b) a way of determining the duration of the reference time of predicates with only. An elaboration of such an account is outside of the scope of the present paper, but a possible treatment is described in Csirmaz (2005; to appear).

To summarize: a uniform treatment of A-adverbs is possible. The definition of A-adverbs must adopt divisibility based on the definitions of Hinrichs (1985) and von Fintel (1997). The resulting definition handles both atoms and gaps successfully. In addition, it extends to reference time predicates with downward entailing quantifiers and - if divisibility is modified and understood as Strawson divisibility - to predicates of times modified by only. The A-adverb can measure the duration of a number of time intervals - including the event time, iterative, habitual or reference time - if the predicate applying to these time intervals is divisible.

19 The notion of Strawson divisibility builds on Strawson entailment (von Fintel 1999), where the entailment relation is similarly restricted. It is worth pointing out that Strawson divisibility also distinguishes an approach based on a modified notion of divisibility and that of Piñón (1999). While the divisibility account readily accounts for Strawson divisibility, it is not immediately clear how the latter approach accounts for these facts.

Acta Linguistica Hungarica 53, 2006 


\subsection{In-adverbs}

In contrast with for-adverbs, in-adverbs (henceforth T-adverbs) modify telic, non-divisible eventuality descriptions. The condition on predicates of times is built into the definition, which differs from that of A-adverbs in requiring a non-divisible predicate of times argument.

(36) for twenty minutes $=\lambda P \cdot \lambda t \cdot\left[\forall t^{\prime} \subset t\left[\exists t^{\prime \prime}\left[t^{\prime} \subseteq t^{\prime \prime} \subset t \& P\left(t^{\prime \prime}\right)\right]\right] \&|t|=20\right.$ minutes $]$

(37) in twenty minutes $=\lambda P . \lambda t \cdot\left[\neg\left[\forall t^{\prime} \subset t\left[\exists t^{\prime \prime}\left[t^{\prime} \subseteq t^{\prime \prime} \subset t \& P\left(t^{\prime \prime}\right)\right]\right]\right] \&|t|=20\right.$ minutes $]$

A telic eventuality description can be modified by a T-adverb because for some subintervals $t^{\prime}$ of the event time - namely, for those that include the left boundary of the event time - there is no proper subinterval $t^{\prime \prime}$ of $t$ for which the predicate holds. For the event predicate János go to the store, for instance, the predicate holds of the event time $t$ and also for those subintervals that include the endpoint of $t$. Crucially, the predicate only applies to those subintervals that include the endpoint. It follows then that those proper subintervals that contain the initial point of $t$ cannot be parts of a proper subinterval of $t$ for which János go to the store also holds.

For A-adverbs, it was proposed earlier that they can measure a number of time intervals and are not restricted to event time modification. The variability of modification can also hold of $i n$-adverbs. It is possible to view in-adverbs as measuring either the event time or the reference time interval, as illustrated below.

(38) (a) János wrote the letter in an hour (event time; the event lasted an hour)

(b) János arrived (with)in an hour (reference time; the event occurred at some point within the hour-long interval)

The different time adverbs measured result in different interpretations of the T-adverb. If the event time is measured, then the event lasts as long as specified. If the adverb measures the reference time, then the event time is contained within the reference time. ${ }^{20} \mathrm{~A}$ maximality implicature

${ }^{20}$ While $i n$-adverbs are ambiguous in measuring either the event time or the reference time, within-adverbs can only measure the reference time. It must also be pointed out that English T-adverbs impose a restriction on the eventuality 
account (where it is implicated, but not asserted, that the event lasted as long as specified by the adverb) can also account for the reference time modification cases. It will be shown in section $\mathbf{5}$, however, that the account of Hungarian T-adverbs needs to appeal specifically to reference time modification by a T-adverb. Since the possibility is independently attested, it may be assumed that English T-adverbs can also modify the reference time.

In the following sections I take the previous definitions of A- and T-adverbs as starting point and note where their Hungarian equivalents diverge. I also assume that time adverbs can show flexibility in measuring time intervals, as shown for English A-adverbs and suggested for T-adverbs above.

\section{A-adverbs in Hungarian}

In the preceding section I argued for a specific definition of divisibility and definitions of English A- and T-adverbs, both based on Hinrichs (1985) and von Fintel (1997). For Hungarian time adverbs, it was pointed out that they are not synonymous, but each adverb shows a different distribution. The Hungarian A-adverbs, enumerated earlier, are italicized below.

$\begin{array}{lll}\text { (39) (a) János másfél óráig futott } & \text { (-ig adverb) } \\ \text { J-nom one.and.half hour-until ran } & \\ \text { 'János ran for an hour and a half' } & \\ \text { (b) János másfél órán keresztül futott } & \text { (keresztül adverb) } \\ \text { J-nom one.and.half hour-on through ran } & \\ \text { 'János ran for an hour and a half' } & \\ \text { (c) János másfél órán át futott } & \text { (át adverb) } \\ \text { J-nom one.and.half hour-on across ran } & \\ \text { 'János ran for an hour and a half' } & \\ \text { (d) János másfél órát futott } & \text { (accusative adverb) } \\ \text { J-nom one.and.half hour-acc ran } & \\ \text { 'János ran for an hour and a half' }\end{array}$

description: independently of the time interval modified, they require the event time predicate to be telic.

Acta Linguistica Hungarica 53, 2006 
The apparently synonymous adverbs differ in various ways. I first consider the adverbs and the time intervals they can modify, suggesting that the range of times that an adverb may modify must be independently specified. In the remaining sections I discuss the adverbs in more detail, pointing out some unexpected differences among them.

\subsection{Times and time adverbs}

The previous example shows that all A-adverbs can measure the event time of a divisible eventuality description, which serves as the basis for classifying these adverbs as A-adverbs. With respect to other time adverbs, however, A-adverbs pattern differently.

It was shown above that English A-adverbs can measure (at least) the event, reference, iterative and habitual time if the appropriate predicate of times is divisible. The reference time can be modified if the reference time predicate contains negation, a downward entailing quantifier, a constituent modified by only, or if the viewpoint aspect is imperfective. The -ig adverbs can modify the reference time in all of these cases:

(40) (a) János tíz percig ment le a lépcsőn (imperfective)

J-nom ten minute-until went down the stair-on

'János was going down the stairs for ten minutes'

(b) János fél óráig nem érkezett meg (negation) J-nom half hour-until not arrived perf

'János didn’t arrive for half an hour'

(c) Fél óráig kevesebb mint három vendég érkezett meg (decreasing half hour-until fewer than three guest-nom arrived perf argument) 'For half an hour fewer than three guests arrived'

(d) Fél óráig csak János érkezett meg (only) half hour-until only J-nom arrived perf

'For half an hour only János arrived'

Iterative and habitual times can also be measured by -ig adverbs, as shown below. The adverbs measure the time span during which the running or blinking event occurred habitually or iteratively, respectively. Hungarian - $i g$ adverbs thus show the same flexibility of time interval modification as English for-adverbs. 
(41) János három évig futott

J-nom three year-until ran

'János ran for three years'

(42) A lámpa tíz percig pislogott (iterative) the lamp-nom ten minute-until blinked

'The lamp blinked for ten minutes'

Let us briefly consider the structural position of the time intervals mentioned. I assume that the event time is an argument of the verb, and is merged within the $\mathrm{vP}$. Iterative and habitual interpretations of an eventuality arise as the consequence of the presence of an ITER or HAB operator, respectively. These operators are merged above the vP, and take a time interval argument that is interpreted as the iterative or habitual time. ${ }^{21}$ Finally, I assume that the reference time is an argument of the head Asp. Asp contains either a perfective or an imperfective head, encoding the relevant aspectual distinction. The proposed structure, with details omitted, is given below.

(43)
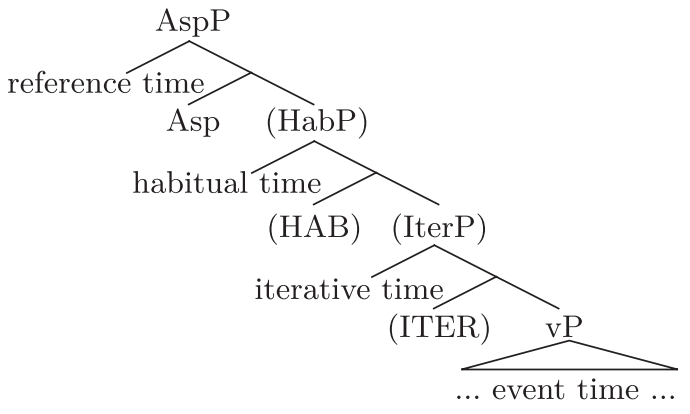

The time intervals in question can all be modified by an - ig adverb, as the previous examples show. This flexibility does not extend to all A-adverbs, though; Hungarian A-adverbs differ in the range of time adverbs that they can measure.

${ }^{21}$ I assume that the two operators are distinct and that both may be present in the structure (as in János coughed for ten years, for instance). For a discussion of these operators and interpretations, see Carlson (1977); Filip-Carlson (1997); de Swart (1998; 2000); and Rimell (2004), among others

Acta Linguistica Hungarica 53, 2006 
Reference time can only be modified by an -ig adverb. Neither of the remaining three adverbs (át, keresztül or accusative adverbs) can measure the duration of the reference time. ${ }^{22}$

(44) (a) János ??két órán át / \#két órán keresztül / \#két órát

J-nom two hour-on across two hour-on through two hour-acc

nem érkezett meg

not arrived perf

'János didn't arrive for two hours'

(b) ??Másfél órán át / \#másfél órán keresztül / \# másfél one.and.half hour-on across one.and.half hour-on through one.and.half órát kevesebb mint három vendég érkezett meg hour-acc fewer than three guest-nom arrived perf 'For an hour and a half, fewer than three guests arrived'

(c) János ?? tíz percen át / \#tíz percen keresztül / \# tíz percet J-nom ten minute-on across ten minute-on through ten minute-acc ment le a lépcsőn went down the stair-on 'János was going down the stairs for ten minutes'

It was shown above that - $i g$ adverbs can measure iterative and habitual times as well. The remaining A-adverbs show variable behavior in this respect. Both át and keresztül can modify these times, while accusative adverbs can modify only iterative, but not habitual time intervals.

(45) (a) János három éven át / három éven keresztül /

J-nom three year-on across three year-on through

?? három évet futott

three year-acc ran

'János ran for three years'

(b) A lámpa tíz percen át / tíz percen keresztül / the lamp-nom ten minute-on across ten minute-on through

(?) tiz percet pislogott ten minute-acc blinked

'The lamp blinked for ten minutes'

${ }^{22}$ These A-adverbs can give rise to the (irrelevant) reading where the arrival or the application process lasts as long as specified by the adverb. In this case, however, the adverb modifies the event time and not the reference time. 
The range of time intervals modified by each A-adverb is summarized below.

(46)

\begin{tabular}{lcccc}
\hline & keresztül & át & $-i g$ & accusative \\
\hline event time & OK & OK & OK & OK \\
\hline iterative time & OK & OK & OK & OK \\
\hline habitual time & OK & OK & OK & $*$ \\
\hline reference time & $*$ & $? ?$ & OK & $*$ \\
\hline
\end{tabular}

In order to account for the variation observed, I assume that the time interval arguments of adverbs are restricted depending on the position where the adverb is generated or externally merged (as discussed, among others, in Thompson 1996). Time adverbs can only measure the duration of a time interval that is local to the merge position of the adverb. Thus in order for an A-adverb to modify the reference time, it must be merged locally to the reference time; a different, lower local external merge site is required for habitual time modification, and so on. The different behavior of A-adverbs can be encoded by assuming that the external merge position of these adverbs is constrained in different ways. Accusative A-adverbs can be merged locally to vP and IterP. Keresztül and át can be merged locally to vP, IterP or HabP. Finally, -ig adverbs show four-way ambiguity in the position where they are merged; they can be merged locally to vP, IterP, HabP or AspP.

The correlation between the surface position of Hungarian adverbs and their interpretation is consistent with the previous locality generalization. In a negated instantaneous eventuality description like János didn't arrive, in (47), a postverbal A-adverb is marked, since it is interpreted as modifying the event time. The reading where the adverb modifies the reference time becomes possible if the adverb is merged higher and precedes the verb.

(47) (a) ??Nem érkezett meg János másfél óráig not arrived perf J-nom one.and.half hour-until 'János didn't arrive for an hour and a half'

(b) Másfél óráig nem érkezett meg János one.and.half hour-until not arrived perf J-nom 'For an hour and a half, János didn't arrive'

The interpretation of the A-adverb in (48) shows a similar distribution. The postverbal adverb is interpreted as determining the duration of the 
sleeping event. A preverbal adverb, in contrast, modifies the reference time and asserts that there was a ninety-minute interval during which János did not sleep. ${ }^{23}$

(48) (a) Nem aludt János másfél óráig not slept J-nom one.and.half hour-until 'János didn't sleep for an hour and a half'

(b) Másfél óráig nem aludt János one.and.half hour-until not slept J-nom 'János didn't sleep for an hour and a half'

The interaction of A-adverbs and time intervals must be stipulated for each adverb. ${ }^{24}$ This restriction can be encoded in various ways; for instance, as part of the definition of the adverb, or as arising from multiple entries for adverbs which can be merged in cartographically distinct positions (possibly as specifiers of different Asp heads) in the structure (Cinque 1999).

(49) The difference in temporal modification among A-adverbs, in terms of the time intervals modified, reduces to the different possible external merge positions of the adverbs.

In addition to the varying interaction with time intervals, A-adverbs show some further differences upon closer inspection. Some of these differences are discussed below.

\subsection{Further differences among adverbs}

First, -ig adverbs are discussed, which show the greatest flexibility in modifying time intervals. A brief description of keresztül and accusative adverbs follows.

${ }^{23}$ If the preverbal adverb is a contrastive topic then it can still modify the event time (K. É. Kiss, p.c.). This is consistent with the hypothesis that first merge position determines the constituents modified by the adverb, and topicalization fails to affect that interpretation.

${ }^{24}$ Arosio (2003) notes that Italian A-adverbs have distinct, non-overlapping distributions. That distribution permits a treatment where the distribution is determined by the semantic properties of the complex predicate containing the adverb. This approach is not viable for Hungarian, given the distribution of the A-adverbs as discussed above. 


\subsubsection{A punctual adverb in disguise}

The A-adverb -ig differs from other time adverbs in that its measure argument is not necessarily durative. ${ }^{25}$ If $-i g$ appears with a punctual argument rather than a durative measure phrase, then it establishes the right boundary of a time interval. Since the phrase két óra is ambiguous between the two interpretations, két óráig is also ambiguous: it is either a punctual or a durative adverb.

(50) János két óráig aludt

J-nom two hour-until slept

'János slept for two hours' (két óra = 'two hours' (durative)

'János slept until two o'clock' (két óra = 'two o'clock' (punctual))

Even though this characterization highlights the ambiguity of -ig, phrasing the distinction this way is deceptive. Durative - $i g$ does not, in fact, measure the duration of a time interval. Rather, it can be seen as specifying the endpoint of a time interval, building on the initial point and the duration elapsed since the initial point. This treatment permits a uniform characterization of $-i g$ and does not require the assumption of some accidental homonymy.

The punctual -ig, where the adverb appears with a punctual argument, does not restrict the eventuality description modified; telic and atelic eventuality descriptions can equally be modified by this adverb.

(51) (a) János 12:30-ig aludt

J-nom 12:30-until slept

'János slept until 12:30'

${ }^{25}$ Despite initial appearances, until adverbs show a behavior significantly different from -ig adverbs. In affirmative environments, until appears with punctual times and modifies only distributive predicates of times. The restriction to distributive event times disappears in the presence of negation - until, with a punctual time argument, can modify telic and atelic eventuality descriptions alike (Karttunen 1974; Mittwoch 1977; Giannakidou 2002; among others). First of all note that the variable behavior of until arises with punctual time expressions, unlike the variation found with $-i g$. In the case of $-i g$, the different restrictions on the divisibility of the predicates of times depend on the temporal argument of $-i g$ (punctual or durative), and are independent of the presence of negation or other downward entailing environments. Furthermore, the different behavior of until is not surprising if it is assumed that in negative sentences, until modifies the (necessarily divisible) reference time rather than the event time.

Acta Linguistica Hungarica 53, 2006 
(b) János 12:30-ig meg érkezett

J-nom 12:30-until perf arrived

'János arrived by 12:30'

I suggest that punctual -ig establishes the right boundary (RB) of a time interval argument of a predicate of times:

(52) $12: 30$-ig $=\lambda P . \lambda t \cdot[P(t) \& R B(t)(12: 30)]$

The predicate of times and the time interval measured varies according to the properties of the eventuality description. If the eventuality description is atelic, as in (51a) above, then the right boundary established by the adverb is that of the event time. In other words, the sleeping eventuality continued (at least) up to 12:30. Whenever the eventuality description is telic, as in (51b), the time interval modified by - $i g$ is the reference time. The eventuality culminated (and therefore the event time ended) before the time established by the adverb. ${ }^{26}$ At this point I merely note the difference, and offer no account for it. In addition to event times, punctual -ig can also establish the right boundary of iterative, habitual and reference times.

Building on the definition of punctual -ig, I suggest that durative - $i g$ also establishes the right boundary of a time interval. Two major differences with respect to punctual $-i g$ are (a) the restriction of the adverb to divisible predicates of times and (b) the presence of a (possibly implicit) punctual time argument $t^{\prime}$ which establishes the left boundary (LB) of the time interval. The original definition of an A-adverb, where the measure phrase directly determines the duration of the time interval, is repeated below for convenience.

(53) húsz percig 'for twenty minutes' $=\lambda P \cdot \lambda t \cdot \lambda t^{\prime} \cdot\left[\mathbf{L B}(t)\left(t^{\prime}\right) \&\right.$ $\left[\forall t^{\prime \prime} \subset t\left[\exists t^{\prime \prime \prime}\left[t^{\prime \prime} \subseteq t^{\prime \prime \prime} \subset t \& P\left(t^{\prime \prime \prime}\right)\right]\right] \quad \& \mathbf{R B}(t)\left(t^{\prime}+[\right.\right.$ twenty minutes $\left.\left.]\right)\right]$

(54) for twenty minutes $=\lambda P . \lambda t \cdot\left[\forall t^{\prime} \subset t\left[\exists t^{\prime \prime}\left[t^{\prime} \subseteq t^{\prime \prime} \subset t \& P\left(t^{\prime \prime}\right)\right]\right] \&|t|=20\right.$ minutes $]$

To encode the restriction of durative -ig adverbs to divisible predicates of times, I appeal to the definition adopted in the preceding section. The left boundary of the time interval of $-i g$ is established by the punctual

${ }^{26}$ The different interpretations of punctual $-i g$ are independent of the duration of the eventuality description. A telic event must culminate before the time of punctual $-i g$ even if the event description is durative. 
argument $t^{\prime}$, and the right boundary is determined by the left boundary and the duration specified. This treatment of $-i g$ adverbs allows a similar treatment of its uses, since - $i g$ always determines the right boundary of a time interval. A durative -ig adverb thus crucially differs from other A-adverbs, which establish duration rather than the endpoint of the relevant time interval. ${ }^{27}$

\subsubsection{Regular spacing of gaps}

With respect to the time intervals that they can measure, it was shown that keresztül and át pattern identically. Both can modify event, habitual and iterative times, but not the reference time interval. I assume that this restriction follows from the stipulated merger sites of the adverbs. Even though their distribution is the same in terms of the time intervals modified, the semantic import of the two adverbs is different. To highlight the difference, let us consider a few scenarios and how the adverbs interact with these.

For a habitual eventuality description, let us assume that János has been learning to play the saxophone for ten years. In the first scenario, he studied and practiced regularly; say, twice a week for ten years. In this case, either an át or a keresztül adverb can measure the duration of the habitual time. In the second scenario, he takes lessons only intermittently and a number of months can pass without taking a lesson or practicing at all. Here modification of the habitual time by an át adverb is more felicitous than by the marked keresztül.

(55) János tíz éven át tanult szaxofonozni

J-nom ten year-on across learned saxophone-V-inf

'János learnt to play the saxophone for ten years' (regularly/intermittently)

27 The suffix -ig also has a spatial goal interpretation, where it yields the endpoint of a path:

János a házig futott

J-nom the house-to ran

'János ran to the house'

In both spatial and temporal uses, the -ig phrase denotes the right boundary of a path or scale. This view permits a homogeneous treatment of both spatial and temporal interpretation of this suffix. In addition, it may reveal a deeper connection between spatial and temporal modification.

Acta Linguistica Hungarica 53, 2006 
(56) János tíz éven keresztül tanult szaxofonozni

J-nom ten year-on through learned saxophone-V-inf

'János learned to play the saxophone for ten years' (regularly/??intermittently)

Both át and keresztül permit gaps between the time intervals for which the predicate of times holds. Intuitively, while át does not require the intervals to be spaced at regular intervals, a constant distance between the time arguments of the predicate is required by keresztül.

A similar difference is shown by the pair in (57). If János was working on the house only intermittently, when he had money, then modification by keresztül is not felicitous. Again, the adverb requires regularly occurring intervals.

(57) (a) János öt éven át építette a házat

J-nom five year-on across built the house-acc

'János was building the house for five years' (continuously or possibly intermittently)

(b) János öt éven keresztül építette a házat

J-nom five year-on across built the house-acc

'János was building the house for five years' (continuously)

In addition, the adverbs differ in whether they can cooccur with overt frequency predicates. While the frequency can be overtly modified by the equivalent of often or seldom if the time adverb is át, this is not possible with keresztül.

(58) (a) János tíz éven át gyakran/ ritkán látogatta az anyósát J-nom ten year-on across often seldom visited the mother.in.law-poss-acc 'For ten years, János often / seldom visited his mother-in-law'

(b) ??János tíz éven keresztül gyakran/ ritkán látogatta az anyósát

J-nom ten year-on through often seldom visited the mother.in.law-poss-acc 'For ten years, János often / seldom visited his mother-in-law'

The restriction on frequency adverbs coocurring with keresztül does not extend to all frequency predicates. Some frequency adverbs that can cooccur with these adverbs are grammatical with keresztül as well:

(59) János két éven keresztül hétfőnként látogatta az anyósát

J-nom two year-on across Monday-on visited the mother.in.law-poss-acc

'For two years, János visited his mother-in-law on Mondays' 
The differences between át and keresztül adverbs are thus the following: keresztül, unlike át, (a) does not allow modification by overt frequency predicates such as often and seldom, and (b) requires regular gaps in habitual eventuality descriptions.

If these generalizations are on the right track, then the marked behavior of keresztül can be treated as stemming from an incorporated frequency predicate regularly. If keresztül contains a frequency adverb, then properties (a) and (b) follow straightforwardly. The regularity of gaps follows from the interpretation of the adverb. The unavailability of overt frequency modification can be ascribed to a restriction on frequency modification, if only one of a subset of frequency predicates can modify the eventuality description. ${ }^{28}$ I propose that the A-adverb definition of Piñón (1999) can be invoked here to define keresztül adverbs. The adverb requires a regular distribution of gaps because frequency adverb regularly is present, as shown below.

(60) tíz éven keresztül ${ }_{1}$ 'for ten years' $=\lambda R \lambda P \lambda e[\exists t[[10$ years $](t) \& \operatorname{Regularly}(e, t, P)]]$

The definition above is true for only those keresztül adverbs that apply to the iterative or habitual time. When keresztül modifies the event time, no implicit frequency adverb is present. Rather, the adverb shares the definition with other A-adverbs:

${ }^{28}$ More remains to be said about the incompatibility of some frequency predicates and keresztül. These overt frequency adverbs can cooccur and show scope interaction:

(i) János gyakran ritkán látogatta az anyósát

J-nom often seldom visited the mother.in.law-poss-acc

'János often seldom visited his mother-in-law'

(= it often happened that (during a certain interval) János seldom visited her)

(ii) János ritkán látogatta gyakran az anyósát

J-nom seldom visited often the mother.in.law-poss-acc

'János seldom visited his mother-in-law often'

(= it seldom happened that (during a certain interval) János visited her often)

If keresztül adverbs contain a covert regularly, then they are expected to cooccur with frequency predicates such as seldom, often, from time to time, etc. It may be also expected that regularly takes narrow scope with respect to these predicates. I leave a more detailed discussion of this issue (including deciding the question of whether multiple frequency predicates are possible at all and accounting for the presence or absence of the different readings) for future research.

Acta Linguistica Hungarica 53, 2006 
(61) két órán keresztül $l_{2}$ 'for two hours' $=\lambda P \cdot \lambda t \cdot\left[\forall t^{\prime} \subset t\left[\exists t^{\prime \prime}\left[t^{\prime} \subseteq t^{\prime \prime} \subset t \& P\left(t^{\prime \prime}\right)\right]\right] \&\right.$ $\&|t|=2$ hours]

To summarize: in order to account for the different interpretations of keresztül, it was necessary to assume two entries for the adverb. Keresztül $l_{1}$ incorporates the frequency predicate regularly and modifies iterative or habitual times, where the frequency predicate can be interpreted. The other entry, keresztül ${ }_{2}$, is restricted to modifying the event time. Át shows no unexpected behavior. I assume that this is due to the default A-adverb definition of át, illustrated in (61).

\subsubsection{An accusative adverb}

Of the four A-adverbs, accusative adverbs have the most restricted distribution. As noted earlier, they can only modify the event and iterative times, but not habitual or reference time. The modification of habitual and iterative times is illustrated below.

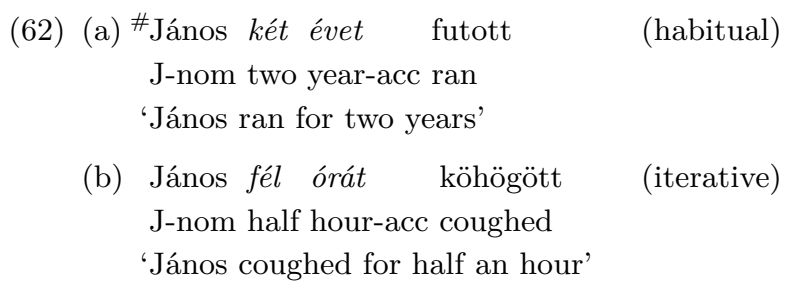

Since the interpretation of accusative and at adverbs, apart from the range of time intervals modified, is similar, I assume that accusative adverbs also share the default definition of A-adverbs.

The restriction of accusative adverbs to event and iterative times, similarly to other time interval restrictions, must be independently stipulated. In contrast with this assumption, Csirmaz (2005; to appear) argues that accusative adverbs are excluded from reference time modification because of the need to license the case marking. ${ }^{29}$ Accusative case licensing requires a first merge position local to the case licensor $\mathrm{v}$ head. Since the adverb is merged low, it cannot modify the reference time, which is merged as the specifier of the higher Asp head. ${ }^{30}$

${ }^{29}$ The proposal is extended to bare time adverbs, which are also assumed to be case marked.

${ }^{30}$ Morzycki (2004) independently suggests a similar restriction on accusative and bare adverbs. 
$(63)$
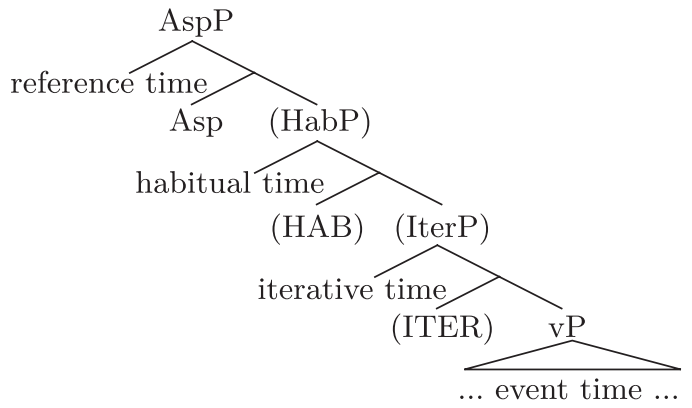

In order for this account to derive the full range of interpretational properties of accusative adverbs, it needs to be shown that the position of the iterative operator ITER is below that of the habitual operator HAB. Crucially, it must also be shown that ITER is sufficiently close to the $\mathrm{v}$ head to permit case licensing of the accusative adverb, while this is not possible if the adverb modifies the habitual time. I leave exploring this possibility for future research, and assume here that the restriction of accusative adverbs is independently stipulated. ${ }^{31}$

\subsection{Towards a typology of A-adverbs}

The discussion of Hungarian A-adverbs started out with a preliminary definition of A-adverbs, based on Hinrichs (1985) and von Fintel (1997) and repeated below.

(64) for twenty minutes $=\lambda P \cdot \lambda t \cdot\left[\forall t^{\prime} \subset t\left[\exists t^{\prime \prime}\left[t^{\prime} \subseteq t^{\prime \prime} \subset t \& P\left(t^{\prime \prime}\right)\right]\right] \&|t|=20\right.$ minutes $]$

${ }^{31}$ Maintaining the case-based account seems ultimately unfeasible. Crosslinguistically, accusative and bare adverbs are excluded from modifying the result time, as illustrated below for English bare adverbs.

(i) János opened the window for two hours

(ii) \# János opened the window two hours

A locality account based on case licensing fails to derive this restriction. In addition, the range of time intervals measured by accusative and bare adverbs is not universally constrained to event time and iterative time, as the following Dutch example shows (M. den Dikken, p.c.).

(iii) Fred heeft twintig jaar (lang) niets dan kabeljauw gegeten

Fred has twenty year long nothing but cod eaten

'Fred ate nothing but cod for twenty years'

(habitual time modification)

Acta Linguistica Hungarica 53, 2006 
I suggested that this definition holds for át and accusative adverbs. Keresztül adverbs are ambiguous. The definition in (64) applies to event time modification. A different definition, repeated below, incorporates the frequency predicate regularly and applies to iterative and habitual times.

(65) tíz éven keresztül ${ }_{1}$ 'for ten years' $=\lambda R \lambda P \lambda e[\exists t[[10$ years $](t) \& \operatorname{Regularly}(e, t, P)]]$

Finally, it was suggested that -ig adverbs establish the right boundary of a time interval rather than measure the duration of the interval. In this respect, an -ig adverb with a durative complement resembles -ig with a punctual time, since both establish the right boundary of some interval complement.

It was also noted that A-adverbs show a variable behavior in terms of the time intervals they can modify. I proposed that the specific range of times be stipulated for each adverb. It is worth pointing out that there is a correlation among the time intervals modified. If an adverb can modify a time interval merged in the structure, then it can modify all of the time intervals merged below that point. - $i g$ adverbs, for instance, can modify all four time intervals: reference, habitual, iterative and event time as well. Keresztül and át adverbs may modify either habitual, iterative or event time. Finally, accusative adverbs can only modify the two lowest time intervals.

\section{T-adverbs}

The scope of the present section is significantly smaller than that of the preceding discussion, since there are only two Hungarian equivalents of in-adverbs: alatt and belül adverbs.

(66) (a) János másfél óra alatt el futott a boltba

J-nom one.and.half hour under away ran the store-to

'János ran to the store in an hour and a half'

(b) János másfél órán belül el futott a boltba

J-nom one.and.half hour-on inside away ran the store-to

'János ran to the store in an hour and a half'

One of the striking differences of English in-adverbs and their Hungarian counterparts is that Hungarian T-adverbs cannot modify the event time of an imperfective eventuality description.

Acta Linguistica Hungarica 53, 2006 
(67) (a) For two weeks, János was writing the novel in a month (but then he realized that he'd only finish in three months)

(b) ${ }^{\#}$ Két hétig János egy hónap alatt / egy hónapon belül two week-until J-nom one month under one month-on inside 'For two weeks, János was writing the novel in a month' írta a regényt wrote the novel-acc

'For two weeks, János was writing the novel in a month'

The constraint on Hungarian T-adverbs can be accounted for by assuming that these adverbs impose a restriction on both the situation and viewpoint aspect properties of the eventuality description that they modify. Both alatt and belül adverbs modify only perfective telic eventuality descriptions. ${ }^{32}$

Even though both T-adverbs impose identical requirements on the aspectual properties of the eventuality description, they measure distinct time intervals. Alatt adverbs measure the duration of the event time and belül adverbs, that of the reference time. The difference in the time intervals modified can be shown in a number of environments. Consider, for instance, how T-adverbs affect the interpretation of an instantaneous eventuality description.

If the event time is modified by an alatt adverb, the eventuality is interpreted as durative (and has a preparatory stage of some duration), as required by the adverb. In (68a), for instance, János started buying lottery tickets two years before he won the prize. If the reference time is modified by a belül adverb, as in (68b), then there is no preparatory stage that would be interpreted as lasting two years. In fact, there is no requirement that a preparatory stage exist at all. The description merely asserts that there was an event of János winning the grand prize at some point within the two-year long interval.

32 The adverbs restrict the aspectual properties of the eventuality description and not divisibility. This is shown by grammaticality of alatt adverb modification of the event time below:

János (két napig) nem válaszolt tíz perc alatt

J-nom two day-until not answered ten minute under

'For two days, Janos didn't answer in ten minutes'

In this case the reference time predicate is divisible (as in the case of imperfective eventuality descriptions), but the viewpoint aspect is perfective - as required by the adverb.

Acta Linguistica Hungarica 53, 2006 
(68) (a) János két év alatt meg nyerte a fónyereményt J-nom two year under perf won the grand.prize-acc

'János won the grand prize in two years'

(b) János két éven belül meg nyerte a fönyereményt J-nom two year-on inside perf won the grand.prize-acc 'János won the grand prize in two years'

The same difference is shown by the following example. The alatt adverb, which modifies the event time, enforces a marked interpretation with a preparatory stage. The resulting interpretation is that Juli was actively engaged in trying to stumble for ten minutes, which she managed to do at the end of the interval. With a belül adverb modification, in contrast, the eventuality description merely asserts that Juli stumbled within a ten-minute interval.

(69) (a) ??Juli tíz perc alatt meg botlott

J-nom ten minute under perf stumbled

'Juli stumbled in ten minutes'

(b) Juli tíz percen belül meg botlott

J-nom ten minute-on inside perf stumbled

'Juli stumbled in ten minutes'

The difference between the two T-adverbs can also be shown with durative predicates. As noted earlier, the reference time of perfective eventuality descriptions properly contains the event time. Thus if the duration of an event is explicitly specified, only alatt adverbs can measure that duration. As an illustration, let us consider a situation where János starts writing a letter at 4 o'clock and finishes exactly at 5 o'clock.

(70) (a) János (pontosan) egy óra alatt meg írta a levelet J-nom exactly one hour under perf wrote the letter-acc

'János wrote the letter in an hour'

(b) \#János (pontosan) egy órán belül meg írta a levelet J-nom exactly one hour-on inside perf wrote the letter 'János wrote the letter in an hour'

In the situation where the event time lasts exactly 60 minutes, modification by an alatt adverb is grammatical, but a belül adverb is not felicitous. This follows if the reference time must properly include the 
event time; the reference time interval must measure longer than sixty minutes in this case.

To conclude this section, let us consider the definitions and restrictions of Hungarian T-adverbs. Both alatt and belül adverbs, just as English in-adverbs, can be defined as given in (71).

(71) in twenty minutes $=\lambda P \cdot \lambda t \cdot\left[\neg\left[\forall t^{\prime} \subset t\left[\exists t^{\prime \prime}\left[t^{\prime} \subseteq t^{\prime \prime} \subset t \& P\left(t^{\prime \prime}\right)\right]\right]\right] \&|t|=20\right.$ minutes $]$

In addition, it must be specified that the two adverbs measure different time intervals: alatt adverbs measure the duration of the event time and belül adverbs, that of reference time. Furthermore, it must be ensured that both adverbs modify only perfective telic eventuality descriptions. While the non-local restriction of T-adverbs on predicates of times is puzzling - with alatt requiring perfective aspect (a property of Asp) and belül requiring telic aspect (a property of $\mathrm{vP}$ ) - it is a restriction that must nevertheless be incorporated into an account of these adverbs.

\section{Time adverbs in Hungarian}

To conclude, let us review the main claims of the paper. First, it was noted that time adverbs can modify not only the event time, but also the iterative, habitual time or the perfect time span, or the reference time. Building on Hinrichs (1985) and von Fintel (1997), I suggested preliminary definitions for Hungarian time adverbs - which serve as the definitions of English time adverbs - that accommodate the possibility of modifying these distinct times.

A discussion of Hungarian time adverbs revealed that the adverbs are not freely interchangeable. Time adverbs (both A- and T-adverbs) differ in the time intervals they can modify. I suggested that this difference should be explicitly encoded as an arbitrary restriction on the adverbs. I showed that Hungarian T-adverbs only differ in the time intervals they measure, but otherwise impose identical restrictions on the eventuality description they modify. I also suggested that for Hungarian A-adverbs, the time intervals that they can measure must be specified and does not follow from independent factors.

Two divergences from the default A-adverb definition were also identified. First, in order to ensure a uniform treatment of -ig adverbs, I proposed that durative - $i g$ adverbs establish the right boundary of the time interval they modify, similarly to punctual $-i g$ adverbs. With durative

Acta Linguistica Hungarica 53, 2006 
-ig adverbs then, the measure phrase measures the distance between the left and right boundaries of the time interval. For keresztül adverbs, I suggested that they are ambiguous. The default definition applies if the adverb measures the event time. For iterative and habitual time modification, in contrast, a different denotation was invoked, where the adverb contains an implicit frequency predicate regularly.

This preliminary study of Hungarian time adverbs reveals a number of consequences for the theory of adverbial modification. It appears necessary to impose explicit restrictions on the range of time intervals that can be modified by specific time adverbs; the distinct possibilities of adverbial modification do not follow readily from independent considerations. In addition, adverbs may impose non-local restrictions on semantic properties: Hungarian T-adverbs constrain both situation and viewpoint aspectual properties, independently of the time intervals they measure. Finally, the discussion suggests that there is no unique definition of time adverbs. While most adverbs conform to a default view of adverbs one that is based on the notion of divisibility of Hinrichs (1985) and von Fintel (1997) - not all adverbs do so. I suggested that the exceptions are Hungarian -ig and keresztül adverbs. The uniform treatment of the spatial and temporal uses of -ig adverbs (which warranted an unorthodox view of measuring duration) suggests that the parallels between the two domains of modifications may extend yet further. An exploration of this connection and the issues noted above is left for further research.

\section{References}

Arosio, Fabrizio 2003. Temporal homogeneity and the Italian perfect. In: Artemis Alexiadou - Monika Rathert - Armin von Stechow (eds): Perfect explorations, 37-66. Mouton de Gruyter, Berlin \& New York.

Bach, Emmnon 1986. The algebra of events. In: Linguistics and Philosophy $9: 5-16$.

Bennett, Michael-Barbara Partee 1972. Toward the logic of tense and aspect in English. System Development Corporation, Santa Monica CA. (Reprinted in Partee, Barbara: Compositionality in formal semantics, Malden MA \& Oxford, Blackwell, 2004.).

Bertinetto, Pier Marco 2001. On a frequent misunderstanding in the temporalaspectual domain: The "perfective-telic" confusion. In: Carlo Cecchetto-Gennaro Chierchia - Maria Teresa Guasti (eds): Semantic interfaces. Reference, anaphora and aspect, 177-210. CSLI Publications, Standford CA.

Carlson, Gregory 1977. Reference to kinds in English. Doctoral dissertation, University of Massachusetts, Amherst.

Acta Linguistica Hungarica 53, 2006 
Cinque, Guglielmo 1999. Adverbs and functional heads: A cross-lingustic perspective. Oxford University Press, New York \& Oxford.

Comrie, Bernard 1976. Aspect. Cambridge University Press, Cambridge.

Csirmaz, Anikó 2005. Semantics and phonology in syntax. Doctoral dissertation, MIT.

Csirmaz, Anikó 2006. Aspect, negation and quantifiers. In: Katalin É. Kiss (ed.): Event structure and the left periphery, 225-54. Springer, Dordrecht.

Csirmaz, Anikó to appear. Measuring time. In: Proceedings of the Penn Linguistics Colloquium 30. University of Pennsylvania Working Papers in Linguistics, Philadelphia.

Demirdache, Hamida - Myriam Uribe-Etxebarria 2000. The primitives of temporal relations. In: Roger Martin-David Michaels - Juan Uriagereka (eds): Step by step. Essays in honor of Howard Lasnik, 157-86. MIT Press, Cambridge MA.

Demirdache, Hamida - Myriam Uribe-Etxebarria 2004. The syntax of time adverbs. In: Jacqueline Guéron - Jacqueline Lecarme (eds): The syntax of time, 143-80. MIT Press, Cambridge MA.

Dowty, David 1979. Word meaning in montague grammar. Dordrecht, Reidel.

É. Kiss, Katalin in press. Jól megoldottuk? Rosszul oldottuk meg? [Have we solved it correctly? Have we solved it incorrectly?]. In: Magyar Nyelv 102.

Filip, Hana-Gregory Carlson 1997. Sui generis genericity. In: Penn Working Papers in Linguistics $4: 91-110$.

Fintel, Kai von 1997. Aspectual classes and aspectual composition. Handout, MIT.

Fintel, Kai von 1999. NPI licensing, Strawson entailment, and context-dependency. In: Journal of Semantics 16:97-148.

Fintel, Kai von-Sabine Iatridou 1997. Since since. Manuscript, MIT.

Giannakidou, Anastasia 2002. UNTIL, aspect and negation: A novel argument for two untils. In: Brandon Jackson (ed.): Semantics and linguistic theory (SALT) 12, 84-103. CLC Publications, Cornell University, Ithaca.

Hinrichs, Erhard 1985. A compositional semantics for Aktionsarten and NP reference in English. Doctoral dissertation, Ohio State University.

Iatridou, Sabine - Elena Anagnostopoulou - Roumyana Izvorski 2001. Some observations about the form and meaning of the perfect. In: Michael Kenstowicz (ed.): Ken Hale: A life in language, 189-238. MIT Press, Cambridge MA. (Reprinted in Artemis Alexiadou - Monika Rathert - Arnim Stechow (eds): Perfect Explorations, 153-204. Mouton de Gruyter, Berlin, 2003.).

Karttunen, Lauri 1974. Until. In: Chicago Linguistic Society $10: 284-97$.

Klein, Wolfgang 1994. Time in language. Routledge, London \& New York.

Krifka, Manfred 1998. The origins of telicity. In: Susan Rothstein (ed.): Events and grammar, 187-235. Kluwer, Dordrecht.

Mittwoch, Anita 1977. Negative sentences with until. In: Chicago Linguistic Society $13: 410-7$.

Moltmann, Frederike 1991. Measure adverbials. In: Linguistics and Philosophy 14 : 629-60.

Morzycki, Martin 2004. Measure DP adverbials: Measure phrase modification in VP. Mansucript, UQAM.

Acta Linguistica Hungarica 53, 2006 
Olsen, Mari Broman 1997. A semantic and pragmatic model of lexical and grammatical aspect. Garland, New York.

Piñón, Christopher 1999. A semantics for durative adverbials. Paper presented at Sinn und Bedeutung, Düsseldorf, 1999.

Rimell, Laura 2004. Habitual sentences and generic quantification. In: Vineeta ChandAnn Kelleher - Angelo Rodriguez - Benjamin Schmeiser (eds): Proceedings of WCCFL 23, 663-76. Cascadilla Press, Somerville MA.

Rothstein, Susan 2004. Structuring events. Blackwell, Malden MA \& Oxford.

Smith, Carlota 1991. The parameter of aspect. Kluwer, Dordrecht.

Stechow, Arnim von 2002. Temporal prepositional phrases with quantifiers. Some additions to Pratt and Francez. Manuscript, Universität Tübingen.

Swart, Henriette de 1998. Aspect shift and coercion. In: Natural Language and Linguistic Theory $16: 347-85$.

Swart, Henriette de 2000. Tense, aspect and coercion in a cross-linguistic perspective. In: Miriam Butt-Tracy Holloway King (eds): Proceedings of the Berkeley Formal Grammar Conference. University of California, Berkeley. (Online publication at http://csli-publications.stanford.edu/LFG/5/bfg00/bfg00deswart.pdf)

Thompson, Ellen 1996. The syntax of tense. Doctoral dissertation, University of Maryland at College Park.

Vendler, Z. 1967. Linguistics in philosophy. Cornell University Press, Ithaca.

Zucchi, Sandro 1991. Negation and aspect. In: Youngkyoon No-Mark Libucha (eds): Proceedings of the Eighth Eastern States Conference on Linguistics, 344-63. CLC Publications, Ithaca. 